\title{
Undergraduate Poll Worker Essay Contest Winners
}

\author{
ABBY PAULSON | AMERICAN POLITICAL SCIENCE ASSOCIATION
}

n fall of 2020, the American Political Science Association's Election Assistance Task Force hosted a short essay contest asking undergraduate students to document their experiences serving as poll workers. The essays written by the three winners and two honorable mentions follow.

\section{Winning Essays}

\section{JACQUELINE FIGUEROA | DENISON UNIVERSITY}

E or the 2020 General Election I worked as a machine judge in Columbus, Ohio. My role consisted of preparing voters at the ballot marker machines so that they could make their choices and then cast their ballots at the ballot counters. I also assisted in setting up and cleaning up the machines, along with balancing the counts for the number of people who voted throughout the day in our polling location. In reflecting on my experience as a poll worker during this election, one incident

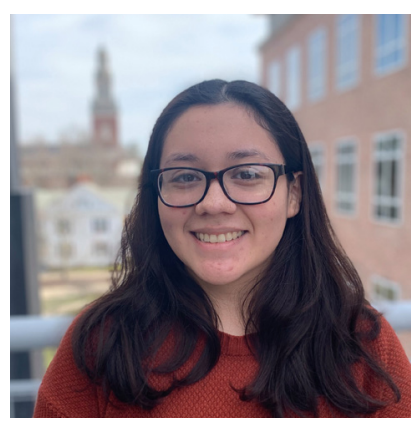
stands out which underscored the accessibility barriers in the voting process. The incident included a voter who was deaf. Since it was my turn to assist the voter at the machines, I approached them and began speaking. The individual then signed to me that they were deaf. Since there was no one in my polling location that knew or understood sign language, it was difficult to let them know about the process, along with where they needed to go after marking their ballots in order to have their ballot casted.

Even though the ballot marker itself gives instructions after the ballot is opened on how to proceed, it is not necessarily clear on why I, as the poll worker, am doing what I am doing at the machine to process the voter, along with directing them to where they need to submit their ballot. I felt like this made the process less transparent for the voter, which is problematic especially at this time when many voters had not used the new machines that Ohio adopted in 2019. This issue underscored the lack of information and inclusion of individuals with many different disabilities in the voting process and how poll workers should deal with individuals that have a disability. The only training I received regarding how to attend to voters with disabilities was that we should only help them if they asked for it. Outside of that, they should be treated as a regular voter. Of course, we should not pathologize voters with disabilities, but that does not mean that we should not have the resources in place to better facilitate the spread of information through different means. I think an important first step would be to include at least one person who knows sign language at the location or having a designated tablet to have that direct communication with hearing-impaired voters.

\section{MASON REECE | RICE UNIVERSITY}

$\mathrm{n}$ the 2018 election, I realized that no matter how election code is written, personal interactions with poll workers can be the difference between enfranchisement and denial of the right to vote. I watched Rice students leave our polling place frustrated, confused and disenfranchised by poll workers who misunderstood Texas' complex voter ID laws. In 2020, rather than watch my peers be unfairly denied again, I took action. I persistently contacted local party leaders and county officials until I was elected precinct chair and appointed as the Election Day judge at Rice, the first student to do so in recent memory. I had never served as a poll worker, but my dedication and proven knowledge of the election code would bring me to lead a team of poll workers and be a cam-

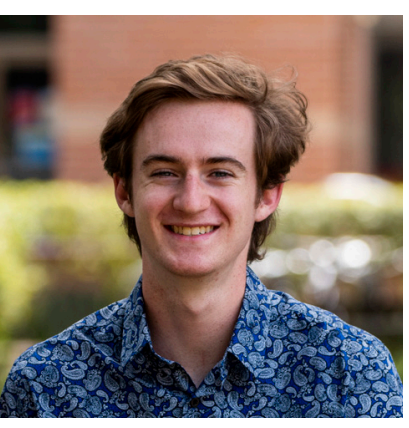
pus-wide voting resource before the election was over.

I recruited 23 students to serve as poll workers, all of them new, and helped them master Texas' confusing election code. In media appearances, I emphasized the power of self-efficacy; students empowering students was our defining ethos. Simultaneously, I collaborated with Rice administrators and student leaders to spread accurate, up to date voting information on all of the complex changes this year.

During early voting, several other Rice students and I served numerous shifts at the Rice vote center, in total helping over 13,000 people exercise their right to vote. We were led by an older, experienced election judge, who helped mentor us in the nuances of the election code and practical considerations for the polling location. My leadership through training and her practical advice prepared all of us to fully serve every voter who came to Rice. 
On Election Day, students would have been disenfranchised without my leadership. One of the very first student voters had a special voter ID, and a non-student, experienced poll worker incorrectly denied the student their right to vote before I noticed, stepped in, and asserted the law. Throughout the day, over 20 students with the same situation were able to fairly vote. My months of reading and memorizing the election code had paid off, I could serve nearly every voter perfectly, making sure they were supported and confident in their vote. I intend to serve again as presiding judge, but I will soon leave this campus. I refuse to be the last student presiding judge, and I am mentoring younger poll workers so they too can ensure an equitable voting process.

\section{WILL SUSSMAN | YALE UNIVERSITY}

M y parents are New York medical doctors, so it is perhaps unsurprising that we contracted COVID- 19 last April, when the state was the epicenter of the virus in the United States. It was frightening. While my mom and I recovered just fine, my dad was hospitalized. He was not at high risk for severe illness, yet was ravaged by the disease. Thankfully he pulled through.

The same cannot be said for more than half a million Americans, many of whom were elderly and therefore at high risk. Aware that poll workers are often retirees, I became concerned

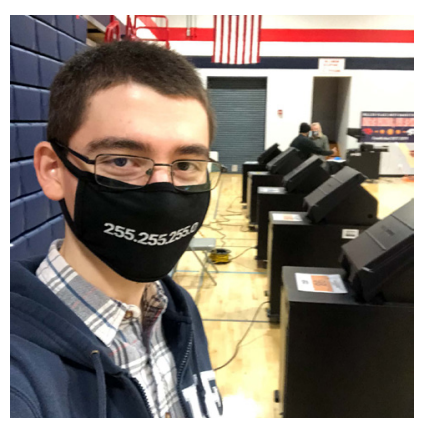
about administration of the November election. Indeed, my county Board of Elections reported that $25 \%$ of poll workers did not show up for the June primary. When I tested positive for antibodies, I signed up to help out.

One of the first questions that was asked of me during the training process was with which party l am registered. "Does that matter?" I asked, taken aback. "Yes," she explained, poll workers work in pairs, one Democrat with one Republican, to ensure that neither party can rig the election. I suppose this makes some sense, though it institutionalizes a two-party system which may not accurately reflect the political diversity of this country.

On Election Day, I witnessed another protection against election rigging: scrupulous accounting by design. Everything was labeled and counted, and nothing was thrown out, not even the pieces of a ballot torn in a paper jam. In the event of a dispute, a simple paper audit would resolve the contention. This has the additional benefit of discouraging foreign adversaries from attempting to hack ballot machines; election interference can be detected, corrected, and sanctioned.

The only real threat to democracy was a combination of voter misbehavior and bad policy. Eligible voters who do not follow the rules cannot be denied their right to vote, so the Board of Elections decided that voters who refuse to wear a mask would have to wait for the polling place to be cleared and then vote while the rest of the line waits outside, creating substantial delay and potentially disenfranchising those who cannot wait so long. Fortunately, we only had one such case, but I think the voter should have been sent to vote elsewhere.

I hope more young people sign up to work the polls. We are needed, now more than ever.

\section{Honorable Mentions}

\section{JACOB MASON | NEBRASKA WESLEYAN UNIVERSITY}

$\mathrm{N}$ ovember 3, 2020 was finally here: Election Day. Beginning at 7 a.m., my four fellow poll workers and I worked to quickly set up the polling station in my hometown of Firth, Nebraska, population 590. By 8 a.m., we were ready to open the doors, letting the massive throngs of voters inside; within the first hour, over 100 voters had cast their ballots. As one of two judges, I accepted ballots from voters while continually sanitizing hundreds of ballot sleeves and voting booths with bleach to stop the spread of COVID- 19.

As a moderate, I am somewhat of a political misfit in my hometown, which is "Trump country" at its finest: white, rural, and conservative. Whereas the media might encourage me to be afraid of my friends and neighbors, the vast majority of voters in my precinct were kind and grateful to be participating in the democratic process. Out of almost 600 voters, only one reacted unkindly to our recom-

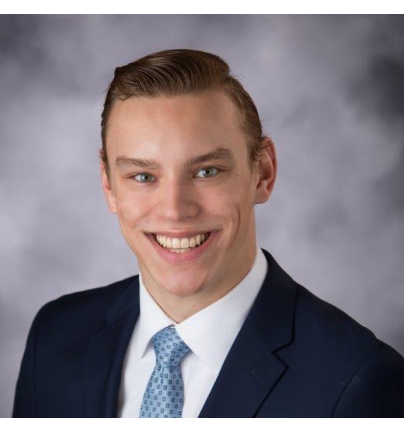
mendation-not requirement-

that he wear a mask. Of the three voters who illegally wore campaign memorabilia inside the polling place, not one refused to remove the offending article of clothing. Dozens of voters took time to personally thank the poll workers, recognizing the risks we took in helping the democratic process to proceed smoothly.

I am proud to call these kind-hearted people my family, friends, and neighbors because they are good people. These are not the angry and violent Trump supporters shown on cable television. Rather, these are the people who took time to talk with me after voting, catching up and chatting about life. Working the polls opened my eyes to the bright side of American democracy, in which people are excited to participate and treat each other with the respect that we all deserve. As the media continues to spin a narrative that conforms to its worldview, I would encourage reporters to hit the road and talk to the voters in places like Firth, NE. In doing so, they will find hard-working Americans laboring to improve their lives and people who are genuinely rooting for the success of democracy. To heal as a nation, we must not fall victim to fear-mongering. If, instead, we can spread kindness, vote, and have conversations-much like the voters in Firth, NE did on November 3rd, 2020-we will be well on our way towards a brighter future in tomorrow's America.

\section{JEAN THOENSEN | GEORGE MASON UNIVERSITY}

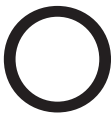
n November 3, 2020, I served as the chief election officer of my polling place in Fairfax County, Virginia, a position I have held for six years. Most of my job is 


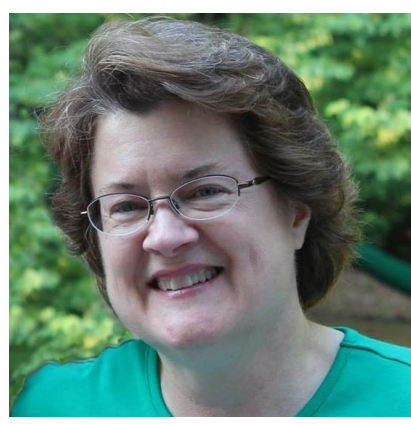

half hour's drive away. Then I started what I call "peeling the onion." Why was she in the wrong place? Did she move? When did she move? Was her voter registration updated correctly? I have to understand the voter's story before I can apply the law correctly. Virginia requires that you cast your ballot in the precinct where you are registered, so being in the right place is important.

She used to live in my precinct. When she moved, she updated her address with the Department of Motor Vehicles. Thanks to a new state law that took effect July 1 st, her new address was forwarded to the Office of Elections, which assigned her to the new precinct. She still lives at the new address, so the solution was simple: send her to the precinct where she is registered to vote.

I politely explained that she just needed to go home and vote at her new precinct. But she wouldn't do it. She refused to wait in line again even though lines were short by that time in the day. I was baffled. She had to drive home anyway, so going to the right precinct wouldn't be an inconvenience.

It was clear that I had lost this voter to something. She exceeded her personal reserve of patience, perhaps? I made my lastditch effort to give her a voting experience by offering a provisional ballot, gently hinting that it would take about the same amount of time as waiting in line again. To my dismay, she chose to cast the provisional ballot, which I knew wouldn't count. She disenfranchised herself by refusing to wait a few minutes at her own precinct.

I strive to say yes to voters-to find some way for every eligible voter to cast a ballot. It broke my heart to watch this voter throw away her vote.

\section{BOOKS BY OUR MEMBERS}

The Black and White Rainbow: Reconciliation,

Opposition, and Nation-building in Democratic South

Africa

Carolyn E. Holmes

University of Michigan Press

The Case for Identity Politics: Polarization, Demographic Change, and Racial Appeals

Christopher T. Stout

University of Virginia Press

China's Gilded Age: The Paradox of Economic Boom and Vast Corruption

Yuen Yuen Ang

Cambridge University Press

Disorienting Neoliberalism: Global Justice and the Outer Limit of Freedom

Benjamin L. McKean

Oxford University Press

The Far Right Today

Cas Mudde

Polity

Informing a Nation: The Newspaper Presidency of Thomas Jefferson

Mel Laracey

University of Michigan Press
International Aid and Democracy Promotion:

Liberalization at the Margins

Bann Seng Tan

Routledge

Power Without Knowledge: A Critique of Technocracy

Jeffrey Friedman

Oxford University Press

Turkey-West Relations: The Politics of Intra-alliance

Opposition

Oya Dursun-Özkanca

Cambridge University Press

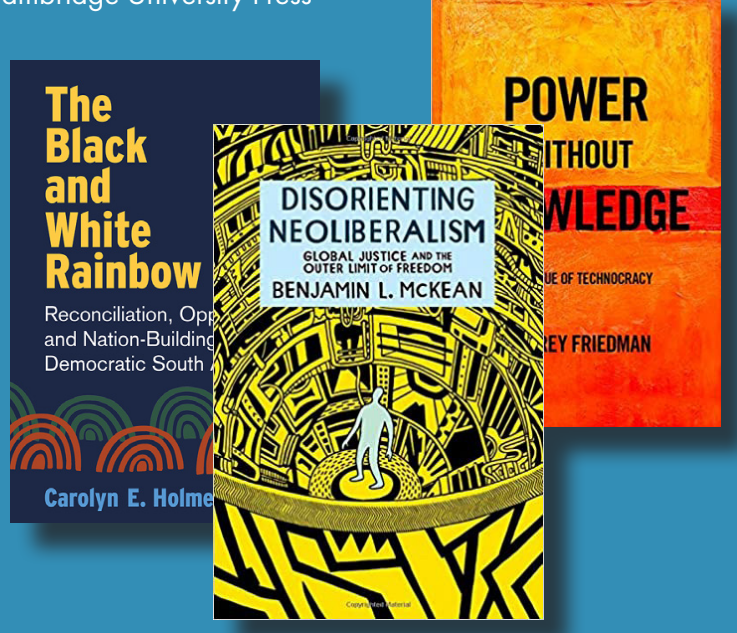

Tell us about your new publication! Email publications@apsanet.org 